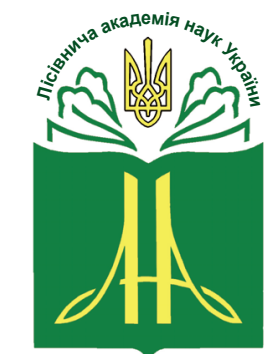

Forestry Academy of Sciences of Ukraine
Наукові праці Лісівничої академії наук України Proceedings of the Forestry Academy of Sciences of Ukraine http://fasu.nltu.edu.ua https://doi.org/10.15421/412112

Article received 2020.11.14

Article accepted 2021.06.10
ISSN 1991-606X print

ISSN 2616-5015 online

(@) $\triangle$ Correspondence author

Liubov Matushevych

Matushevych@nubip.edu.ua
Heroiv Oborony str., 15, Kyiv, 03041, Ukraine

\title{
Моделювання первинної продукції компонентів надземної частини дерев сосни звичайної Східного Полісся України
}

\author{
Л.М. Матушевич' , П.І. Лакида²
}

Первинну продукиію компонентів надземної фітомаси (стовбура і крони) оичінено для дерев сосни звичайної, які ростуть переважно у чистих та мішаних (домішка від 1 до 3 од.) соснових насадженнях штучного походження Східного Полісся Украӥни. Насадження високопродуктивні (II, I, I ньо- та високоповнотні, ростуть у свіжих борах ( $\left.A_{2}\right)$, суборах (B, та сугрудах (C,). Використано дані 80 тимчасових пробних плош (ТПП), які закладено у соснових деревостанах Сумської (36 ТПП) та Чернігівської (44 ТПП) областей. Зрубано й обміряно 900 модельних дерев (МД) сосни звичайної, з яких 226 МД опрацьовано з пофракиійним оцінюванням компонентів надземної фітомаси та 674 МД-без оцінювання фітомаси крони. Обмір моделей і розрахунки первинної продукиії компонентів надземної фітомаси дерев сосни звичайної виконано за допомогою удосконалених загальноприйнятих методів та розробленого алгоритму.

Сукупність значень дослідного матеріалу характеризується їх нормальним розподілом за віком, діаметром, висотою дерев та відносною повнотою насаджень. Встановлено тісноту зв 'язку між досліджуваними показниками модельних дерев сосни звичайної (від помірного - -0,31<r<-0,50, до дуже високого - $r>0,91$ ); слабкої тісноти зв'язок $(0,11<r<0,30)$ виявлено між повнотою насаджень та часткою поточного об 'ємного приросту з показниками компонентів фітомаси крони дерев.

Розраховано регресійні математичні моделі для оцінювання абсолютного та відносного поточного об 'смного приросту деревини стовбурів, об 'єму кори стовбурів, маси деревини, кори гілок $і$ маси хвої в абсолютно сухому стані, в яких аргументами є вік та діаметр дерев $\left(R^{2}=0,72-0,92\right)$. Для частки хвої 1-го року зв'язок з віком дерев обернений та помірний, але значущий на 5\%-му рівні $\left(R^{2}=0,33\right)$.

Розроблені нормативні таблиці первинної стовбурової продукиії деревини та первинної продукції надземної частини дерев сосни звичайної показали, щзо за однакового діаметра зі збільшенням віку дерев первинна продукиія стовбурової деревини збільшується лише до певного віку, а досягнувши максимуму - зменшується. Зі збільшенням діаметра за однакового віку первинна продукція стовбурової деревини зростає. Первинна продукція надземної частини дерев, подібно до окремих компонентів надземної фітомаси, зі збільшенням віку та діаметра також збільшується. У типових лісорослинних умовах Східного Полісся середньовікове дерево (50 років) сосни звичайної в надземній частині може нагромаджувати 15,22 кг·рік-1 первинної продукиії.

Ключові слова: тимчасова пробна площа; модельні дерева; алгоритм розрахунку; поточний приріст; компоненти фітомаси; математичні моделі; первинна продукиія.

Матушевич Любов Миколаївна - член-кореспондент Лісівничої академії наук України, кандидат сільськогосподарських наук, доцент кафедри таксації лісу та лісового менеджменту. Національний університет біоресурсів та природокористування України, вул. Героїв Оборони, 15, м. Київ, 03041, Україна. Тел.: 044-527-85-23;+38-067-944-82-75. E-mail: Matushevych@nubip.edu.ua ORCID: https://orcid. org/0000-0001-7282-3215

2 Лакида Петро Іванович - академік Лісівничої академії наук України, перший віце-президент ЛАН України, професор, доктор сільськогосподарських наук, директор навчально-наукового Інституту лісового і садово-паркового господарства. Національний університет біоресурсів та природокористування України, вул. Героїв Оборони, 15, м. Київ, 03041, Україна. Тел.: 044-527-85-28; +38-067462-80-43. E-mail: lakyda@nubip.edu.ua ORCID: https://orcid.org/0000-0003-3639-2969 
Вступ. Для вивчення сучасного стану й функціонування лісових екосистем, первинна продукція є виключно важливим показником 3 погляду глобального оцінювання ролі лісів, зокрема й лісів Східного Полісся України, як стабілізуючого елемента стійкості кліматичних систем планети. Проте за темою первинної продукції лісів, як на території України, так і інших держав, нагромаджено ще недостатню кількість робіт, а в опублікованих матеріалах середня оцінка первинної продукції для ділянок, вкритих лісовою рослинністю, може відрізнятись більш ніж у два рази, що вказує на доцільність іiі системного аналізу (Gower, Krankina, Olson, Apps, Linder, \& Wang, 2001; Швиденко, Щепащенко, Ваганов, Нильсон, 2008, Швиденко, Лакида, Щепащенко, Василишин, Марчук, 2014; Білоус, Миронюк, Мацала, Дячук, 2018).

Починаючи 3 минулого століття і до сьогодні, науковцями всього світу значну увагу приділено дослідженню первинної продукції лісів, що збагатило лісівничу літературу науковими працями цього напряму (М'якушко, 1972, Clark, Brown, Kicklighter, Chambers, Thomlinson, \& Ni, 2001, Lieth, 1975; Tateno, Hishi, \& Takeda, 2004; Уткин, 1970 та ін.), які стали підгрунтям для удосконалення, розширення, оновлення існуючих методик та розробки нових методичних підходів до оцінювання первинної продукції, як стабілізуючого екосистемного елемента в умовах глобальних кліматичних змін.

Розроблена значна кількість різних методів оцінювання первинної продукції (Cramer et al., 1999; Кнорре, Кирдянов, Круглов, Силкин, 2005; Ольчев, 2016; Швиденко, Нильссон, Столбовой, Рожков, Глюк, 2001; Усольцев, 2007; Уткин, 1982; Уткин, Замолодчиков, Пряжников, 2003; Ворнов, Усольцев, Часовских, 2010 та ін.), але й досі не сформовано єдиний підхід стосовно принципів формування баз даних про біотичну продуктивність лісів (Jenkins, Chojnacky, Heath, \& Birdsey, 2004; Усольцев, 2010), хоча вже тривалий час учені висловлюють стурбованість щодо їх якісної наповненості (Cannell, 1989; Clark et al., 2001; Vogt, Grier, \& Vogt, 1986) та недостатнього обсягу інформації для екологічного моделювання (Свирежев, 1981).

Одним із завдань національної статистичної інвентаризації лісів України є отримання вичерпної характеристики лісових ресурсів, зокрема, величини та динаміки приросту (продукції) компонентів дерев i деревостанів. Посилюють та конкретизують вимоги до складу і якості наповнення інформації про ліси ратифікація Україною низки міжнародних угод, які прямо чи опосередковано стосуються лісів, а також євроінтеграційна спрямованість політики держави (Лакида, Василишин, Матушевич, Бала, Лакида, 2017; Швиденко та ін., 2014; Швиденко, Лакида, Василишин, 2015).

Беручи до уваги вище викладене, дослідження первинної продукції дерев і деревостанів головних лісотвірних порід Східного Полісся України, які розглядають як ключове завдання у вирішенні енергетичних та екологічних проблем, впрова- дженні моніторингу довкілля 3 оцінкою вуглецевої та кисневої продуктивності лісової біоти території, що займає лівобережну частину зони Полісся України, є своєчасними та актуальними.

Об'єкти та методика досліджень. Об'єкт дослідження - чисті та мішані соснові насадження штучного походження у Східному Поліссі України. Предмет дослідження - первинна продукція компонентів фітомаси надземної частини дерев сосни звичайної у штучних деревостанах Східного Полісся України. Мета роботи - розробити алгоритм, математичні моделі та нормативні таблиці з оцінювання первинної продукції компонентів надземної фітомаси дерев сосни звичайної.

Для дослідження надземної первинної продукції сосни звичайної використано експериментальний матеріал, зібраний під час польових робіт впродовж 1981-2017 pp. багатьма науковцями (П. І. Лакида, 2002; Лакида та ін., 2016; Лакида та ін., 2011). Тимчасові пробні площі (ТПП) опрацьовані за методикою П.І. Лакиди (2002). Частина ТПП опрацьована за модифікованою методикою досліджень біотичної продукції компонентів крони дерев (Лакида, Матушевич, Блищик, 2012, 2018; Лакида, Матушевич, 2012) та методикою 3 можливістю оцінення площі листкової поверхні насаджень (Лакида, Матушевич, Ловинська, 2015; Лакида, Матушевич, 2015; Матушевич, Лакида, 2014, 2018). Всього використано 80 ТПП, які закладено у соснових деревостанах Сумської (36 ТПП) та Чернігівської (44 ТПП) областей, на території, яку віднесено до зони Східного Полісся. На ТПП зрубано й обміряно 900 модельних дерев (МД) сосни звичайної, з яких 226 МД опрацьовано з пофракційним оцінюванням компонентів надземної фітомаси та 674 МД - без оцінювання фітомаси крони.

Тимчасові пробні площі закладали у чистих i мішаних соснових насадженнях штучного походження, де зрубували модельні дерева, на яких визначали необхідні таксаційні показники. Окрім них, ваговим методом визначали масу деревної зелені, масу живих і мертвих гілок. Перед зрубуванням МД вимірювались параметри їхньої крони. Здійснювали також лінійний обмір та визначали масу річного приросту модельних гілок (МГ), узятих з модельних дерев.

ТПП представлені усіма класами віку - від молодняків до стиглих соснових насаджень (IX клас віку в експлуатаційних лісах), однак $з$ перевагою молодняків і середньовікових деревостанів. Загалом, це чисті сосняки або з незначною домішкою (від 1 до 3 од.) у складі насадження інших порід, які $\epsilon$ високопродуктивними (II, I, I ${ }^{\mathrm{a}}$ i вище класи бонітету), що в основному відображає продуктивність соснових насаджень у регіоні досліджень. Вони, зазвичай, формують середньо- та високоповнотні соснові деревостани, меншою мірою - низькоповнотні. Соснові насадження досліджено у свіжих борах $\left(A_{2}\right)$, суборах $\left(B_{2}\right)$ та сугрудах $\left(C_{2}\right)$ Східного Полісся України. В процесі досліджень розробле- 
но та запропоновано для практичного використання алгоритм оцінювання первинної продукції компонентів надземної фітомаси дерев сосни звичайної (рис. 1). Методика обробки модельних об'єктів на ТПП для визначення первинної продукції дерев і деревостанів значно складніша, порівняно $з$ методикою оцінювання тільки наявної в ньому фітомаси (Лакида, 2002; Лакида, Матушевич, 2006; Усоль- цев, 2007, 2010; Усольцев, Залесов, 2005; Уткин, 1982). Тому виникає необхідність у розробленні нових та удосконаленні існуючих методів оцінювання біотичної продуктивності лісів, які зможуть забезпечити збір експериментальних даних необхідної точності й детальності для оцінювання первинної продукції не тільки компонентів фітомаси стовбурів, а й компонентів фітомаси крони дерев.

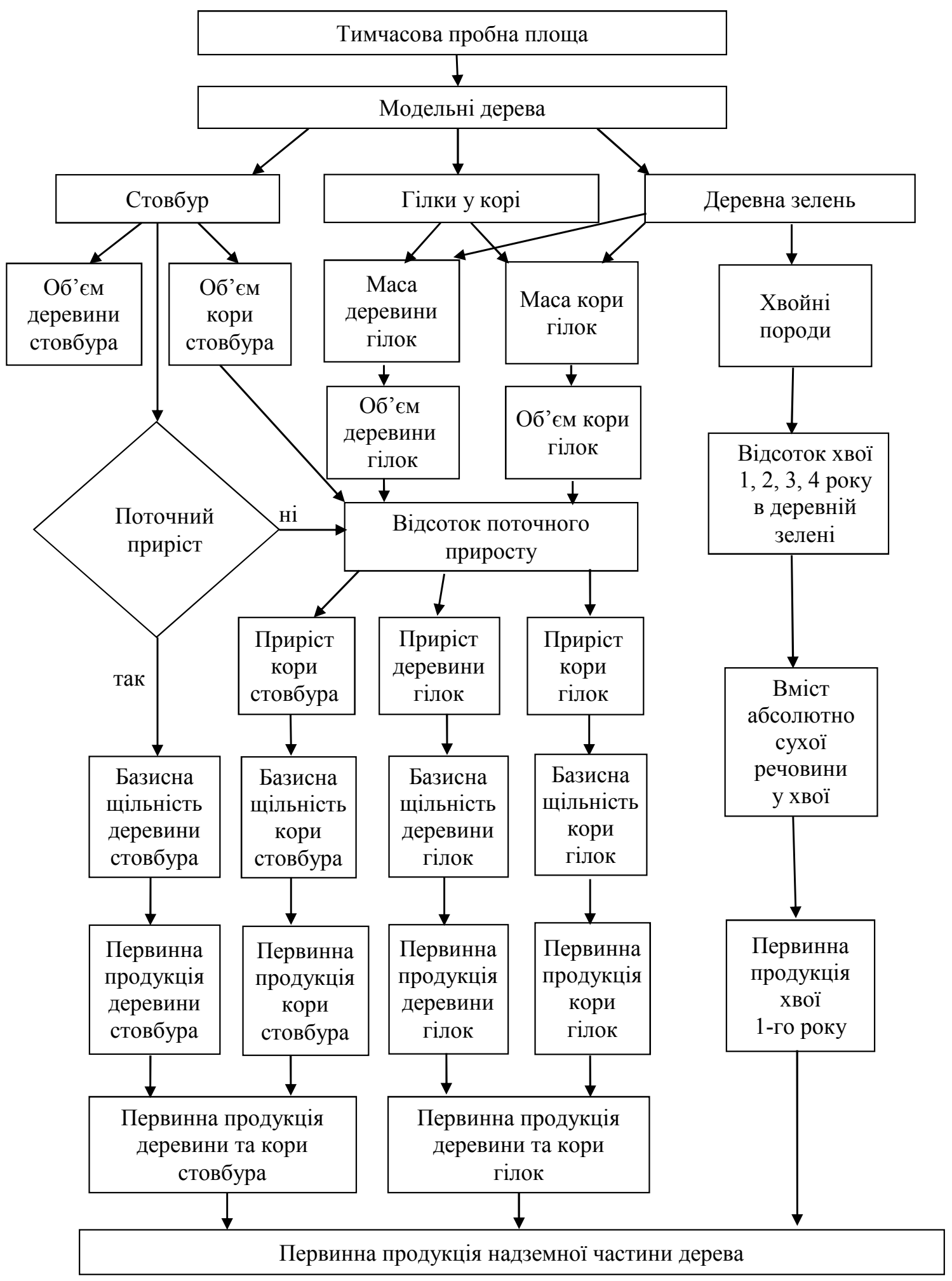

Рис. 1. Алгоритм оцінювання первинної продукції компонентів надземної фітомаси дерев сосни звичайної 
Первинна (біотична) продукція $є$ кількісною характеристикою біопродукційного процесу, яку найчастіше характеризують поточним приростом компонентів фітомаси дерев і деревостанів. Первинну продукцію компонентів стовбурів дерев поділяють на деревину та кору, а компонентів крони дерев - на зелені асимілюючі органи, деревину та кору гілок i генеративні органи.

Результати та обговорення. Для 3'ясування однорідності зібраного дослідного матеріалу, виявлення закономірностей розподілу досліджуваних показників, забезпечення адекватності та коректності математичних моделей зв'язку, побудованих 3 метою оцінювання первинної продукції фракцій фітомаси дерев сосни звичайної, здійснювали статистичний аналіз даних.

Статистики розподілу основних таксаційних показників модельних дерев сосни звичайної наведено в табл. 1.
Представлена сукупність значень у натуральних величинах характеризується нормальним розподілом за віком (хоча його показник асиметрії дещо перевищує межу критичного значення $A>1,0)$, діаметром, висотою дерев та відносною повнотою насаджень, в яких вони росли. Розподіл показників віку, діаметра та висоти дерев має правосторонню скошеність (додатні значення), а показник відносної повноти насаджень, навпаки, лівосторонню скошеність (від'ємне значення). Відрізняються від нормального розподілу в натуральних величинах показники об'єму стовбура у корі, без кори, об'єму кори стовбура, поточного об'ємного приросту та частки поточного об' ємного приросту модельних дерев (див. табл. 1). Для цих величин спостережено правосторонню асиметрію, яка значно перевищує критичне значення, а також високу стрімкість; показники ексцесу значно перевищують допустиме значення $(E>1,2)$ і характеризуються додатним показником.

Таблиия 1

Статистики розподілу основних таксаційних показників модельних дерев сосни звичайної (верхній рядок - натуральні величини, нижній - логарифмічні)

\begin{tabular}{|c|c|c|c|c|c|c|}
\hline \multirow{2}{*}{ Ознака } & \multicolumn{2}{|c|}{ Значення } & \multicolumn{4}{|c|}{ Статистики } \\
\hline & $\min$ & $\max$ & $\bar{X}$ & $\sigma$ & $A$ & $E$ \\
\hline \multirow{2}{*}{$a$, років } & 8 & 85 & 33 & 15,6 & 1,033 & 0,865 \\
\hline & 2,1 & 4,4 & 3,4 & 0,5 & $-0,195$ & 0,122 \\
\hline \multirow{2}{*}{$d, \mathrm{~cm}$} & 1,3 & 38,7 & 14,0 & 6,6 & 0,557 & $-0,138$ \\
\hline & 0,3 & 3,7 & 2,5 & 0,5 & $-0,791$ & 0,949 \\
\hline \multirow{2}{*}{$h, \mathrm{M}$} & 1,8 & 30,8 & 14,0 & 5,8 & 0,292 & $-0,457$ \\
\hline & 0,6 & 3,4 & 2,5 & 0,5 & $-0,980$ & 1,419 \\
\hline \multirow{2}{*}{$v_{c m y x}, \mathrm{M}^{3}$} & 0,001 & 1,580 & 0,173 & 0,204 & 2,142 & 5,956 \\
\hline & $-6,908$ & 0,457 & $-2,505$ & 1,402 & $-0,585$ & 0,086 \\
\hline \multirow{2}{*}{$v_{\text {стб бк }}, \mathrm{M}^{3}$} & 0,001 & 1,489 & 0,153 & 0,187 & 2,246 & 6,719 \\
\hline & $-6,908$ & 0,398 & $-2,664$ & 1,448 & $-0,608$ & 0,141 \\
\hline \multirow{2}{*}{$v_{\kappa c m}, \mathrm{M}^{3}$} & 0,000 & 0,104 & 0,019 & 0,019 & 1,524 & 2,322 \\
\hline & $-6,908$ & $-2,263$ & $-4,444$ & 1,114 & $-0,407$ & $-0,524$ \\
\hline \multirow{2}{*}{$z_{v}, \mathrm{M}^{3} \odot \mathrm{pi \kappa}^{-1}$} & 0,0001 & 0,0418 & 0,0072 & 0,0068 & 1,700 & 3,259 \\
\hline & $-9,2103$ & $-3,1749$ & $-5,4228$ & 1,0875 & $-0,537$ & 0,035 \\
\hline \multirow{2}{*}{$\mathrm{p}_{\mathrm{v}}, \%$} & 1,3 & 29,4 & 7,8 & 4,8 & 1,808 & 4,241 \\
\hline & 0,29 & 3,38 & 1,89 & 0,56 & 0,081 & $-0,120$ \\
\hline \multirow{2}{*}{$m_{y \kappa}^{2 i n}$, Кг } & 0,15 & 99,54 & 6,62 & 10,43 & 4,741 & 31,838 \\
\hline & $-1,90$ & 4,60 & 1,23 & 1,13 & 0,138 & $-0,048$ \\
\hline \multirow{2}{*}{$m_{\partial}^{2 i . \tau}, \kappa \Gamma$} & 0,10 & 20,90 & 3,11 & 3,89 & 3,158 & 11,314 \\
\hline & $-2,30$ & 3,04 & 0,605 & 1,08 & $-0,299$ & 0,383 \\
\hline \multirow{2}{*}{$m_{\kappa}^{2 i .]}$, кг } & 0,05 & 4,49 & 1,19 & 0,98 & 1,444 & 2,161 \\
\hline & $-3,00$ & 1,50 & $-0,22$ & 1,02 & $-0,810$ & 0,379 \\
\hline \multirow{2}{*}{$m_{x \beta}$, Кг } & 0,08 & 24,29 & 3,76 & 3,86 & 2,378 & 6,864 \\
\hline & $-2,53$ & 3,19 & 0,90 & 0,95 & $-0,169$ & 0,047 \\
\hline \multirow{2}{*}{$\Pi$} & 0,29 & 1,21 & 0,80 & 0,17 & $-0,146$ & 0,462 \\
\hline & $-1,24$ & 0,19 & $-0,24$ & 0,23 & $-1,146$ & 2,767 \\
\hline
\end{tabular}

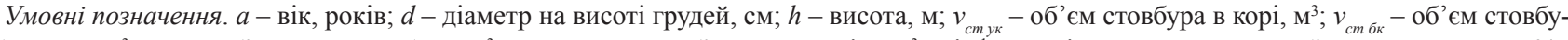

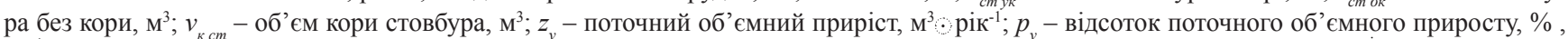
$m_{y \kappa}^{2 i n}$ - фітомаса гілок у корі в абсолютно сухому стані, кг, $m_{\partial}^{2 i . n}-$ фітомаса деревини гілок в абсолютно сухому стані, кг, $m_{\kappa}^{2 i . \Omega}-$ фітомаса кори гілок в абсолютно сухому стані, кг, $m_{x \beta}-$ фітомаса хвої в абсолютно сухому стані, кг та $\Pi$-відносна повнота насаджень 
Для показників об'єму стовбура у корі та без кори мінливість абсолютних значень $(\sigma)$ перевищує їхнє середнє значення $(\bar{X})$, а для показників об'єму кори стовбура ці показники подібні, що також вказує на відмінність від нормального розподілу цих величин.

Значно знижують мінливість абсолютних значень досліджуваних величин їхні логарифми, де показники середньоквадратичного відхилення не перевищують середніх значень й значно нижчі від них. Показники асиметрії та ексцесу логарифмічних величин наближаються до нуля. Значення асиметрії всіх оцінюваних показників, окрім частки поточного об'ємного приросту модельних дерев, набувають від'ємного знаку (мають лівосторонню скошеність). Стрімкість розподілу показників, відмінних від нормального розподілу в натуральних величинах, під час логарифмування значно знижується, i для об'єму кори стовбурів і частки об'ємного поточного приросту дерев набуває від'ємних значень. Переведення вихідних даних у натуральні логарифми, значення яких забезпечені нормальним розподілом, не виявили позитивного результату розподілу для показників висоти дерев та повноти насаджень. Логарифмування цих величин, навпаки, призвело до значної (на межі критичного значення і вище) лівосторонньої асиметрії $(A=-0,98$ та $-1,15)$ та значної (перевищує критичне значення) додатної стрімкості $(E=1,42$ та 2,77).

Відмінними від нормального розподілу для дерев сосни звичайної (див. табл. 1) як у натуральних, так і логарифмічних величинах, $є$ сукупність значень фітомаси гілок у корі, деревини та кори гілок, а також хвої в абсолютно сухому стані. Статистики цих показників у натуральних величинах мають високу дисперсію, асиметрію та ексцес, які вирівнюються під час логарифмування досліджуваних ознак та наближають їх до нормального розподілу. Не перевищують допустимих значень показники асиметрії, які для маси деревини, кори гілок і хвої змінюють знак $з$ додатного на від'ємний та ексцесу (від'ємний лише для маси гілок у корі), але середньоквадратичне відхилення цих величин залишається високим, яке близьке до середнього значення або його перевищує. Варто відзначити, що на масу гілок і листя (хвої) впливають параметри крони дерев, величина яких істотно залежить від виду деревних рослин, їхнього віку, лісорослинних умов, густоти насадження, типу змішування порід, проведених лісогосподарських заходів тощо. Через це їхня кількість і маса постійно змінюються, що ускладнює відповідність показників фітомаси компонентів крони нормальному розподілу (Лакида, Матушевич, 2006).

Встановлення тісноти зв'язку між таксаційними показниками модельних дерев сосни звичайної та 3 відносною повнотою насаджень здійснювали за допомогою кореляційного аналізу з використанням коефіцієнтів кореляції Пірсона шляхом попарного співставлення їхніх значень (Горошко, Миклуш,
Хомюк, 2004; Никитин, Швиденко, 1978). Отримані значення коефіцієнтів кореляції, показали наявність дуже високої, високої, значної та помірної тісноти зв'язку між усіма досліджуваними показниками модельних дерев сосни звичайної. Встановлена слабка тіснота зв'язку між цими показниками і повнотою насаджень, а також частки поточного об'ємного приросту з показниками компонентів фітомаси крони дерев.

Для пошуку найінформативніших $\mathrm{i}$ логічних факторів впливу на результативну ознаку, детально вивчали абсолютний і відносний поточний об'ємний приріст, як основу оцінювання первинної продукції для усіх надземних компонентів фітомаси дерев. Для цих показників, окрім статистичного та кореляційного, здійснили ще й графоаналітичний аналіз їхньої залежності від морфометричних ознак дерева (віку, діаметра, висоти) й відносної повноти насаджень (рис. 2, 3). Загалом, абсолютний поточний об'ємний приріст сосни звичайної зі збільшенням віку, діаметра, висоти дерев і відносної повноти насаджень зростає (див. рис. 2). Однак його значення мають мінливість у межах фіксованих значень цих показників. Особливо значну варіабельність спостережено для сталого віку дерев та повноти насаджень. Відносний поточний об'ємний приріст сосни звичайної зі збільшенням віку, діаметра, висоти дерев та відносної повноти насаджень спадає (див. рис. 3).

Мінливість відносного об'ємного приросту деревини стовбурів сосни суттєво знижується за фіксованих значень віку, й слабше - від висоти модельних дерев та повноти насаджень, дещо зростаючи для діаметра модельних дерев (див. рис. 3). Ці дані використано під час вибору типу та розробки математичних моделей кількісної оцінки зв'язку.

Виходячи з умов практичного використання, для оцінки абсолютного поточного приросту й подальшого дослідження первинної продукції стовбурової деревини дерев, найінформиативнішою й практично доступною є модель 1 (табл. 2) із включенням віку, діаметра та експоненти віку дерев $\left(\mathrm{R}^{2}=0,89\right)$. Для оцінювання відносного поточного приросту деревини стовбурів й подальшого вивчення первинної продукції кори стовбурів дерев, деревини та кори гілок дерев, відповідно до алгоритму розрахунку (див. рис. 1), найінформативнішою і найпрактичнішою $є$ модель 2 (див. табл. 2) із включенням віку, діаметра та експоненти віку дерев $\left(\mathrm{R}^{2}=0,89\right)$.

Розраховані за вибраними рівняннями абсолютний (1) та відносний (2) поточні прирости деревини стовбурів дерев сосни звичайної порівнювали 3 фактичним накладанням їх на графік та оцінюванням їхніх залишків, що підтвердило адекватність залежної змінної. Зміну розрахованого абсолютного поточного приросту деревини стовбурів за обраною моделлю (1) наведено на рис. 4, а відносного поточного приросту деревини стовбурів за обраною моделлю (2) - на рис. 5. 
a)

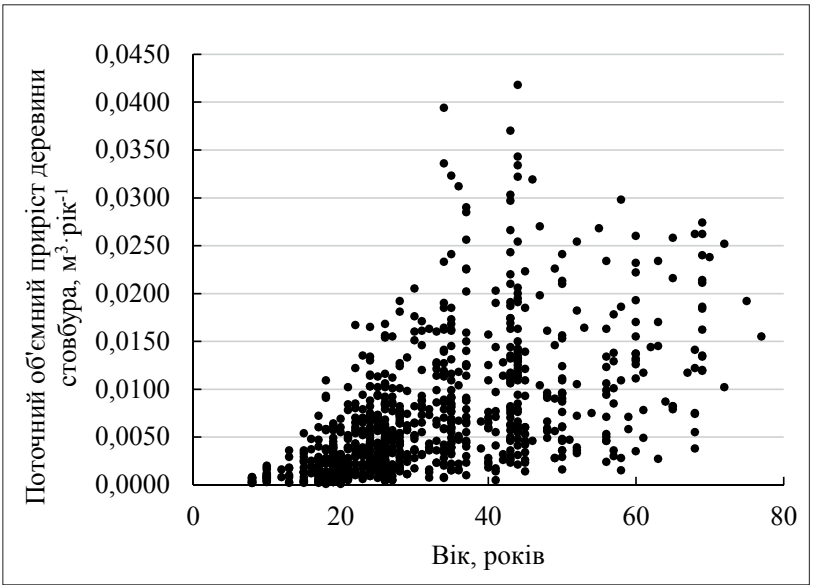

б)

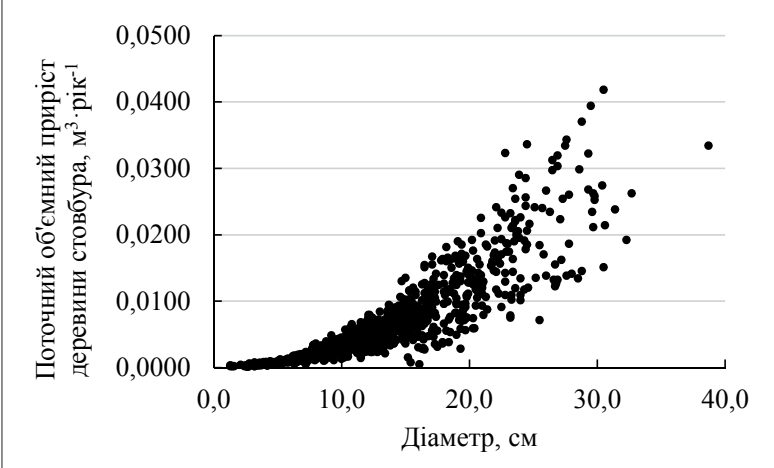

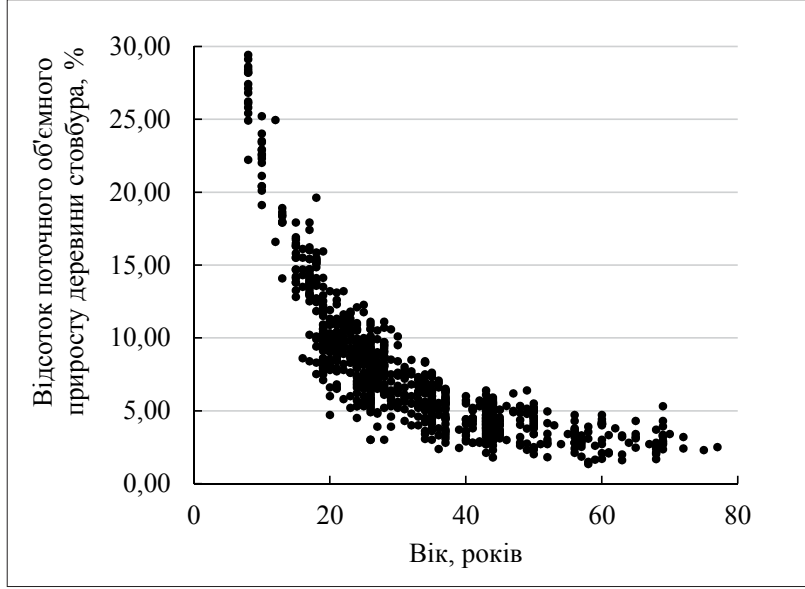

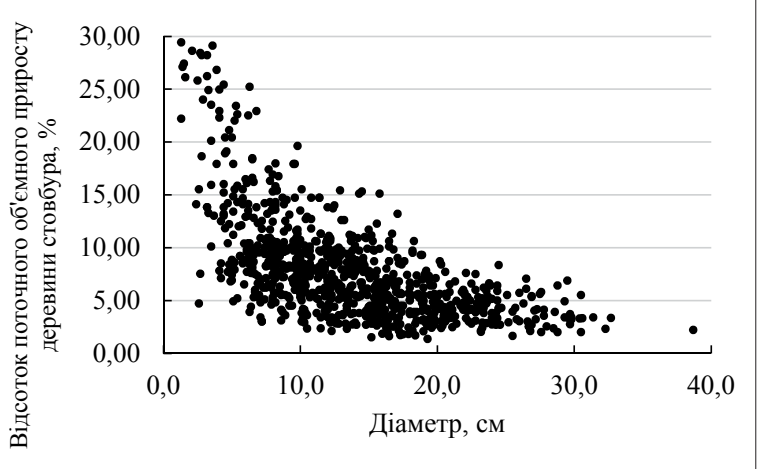

Рис. 2. Залежність абсолютного ( ${ }^{3} \cdot$ рік $\left.^{-1}\right)$ та відносного (\%) поточного об'ємного приросту деревини стовбура від: а) віку; б) діаметра модельних дерев сосни звичайної

a)

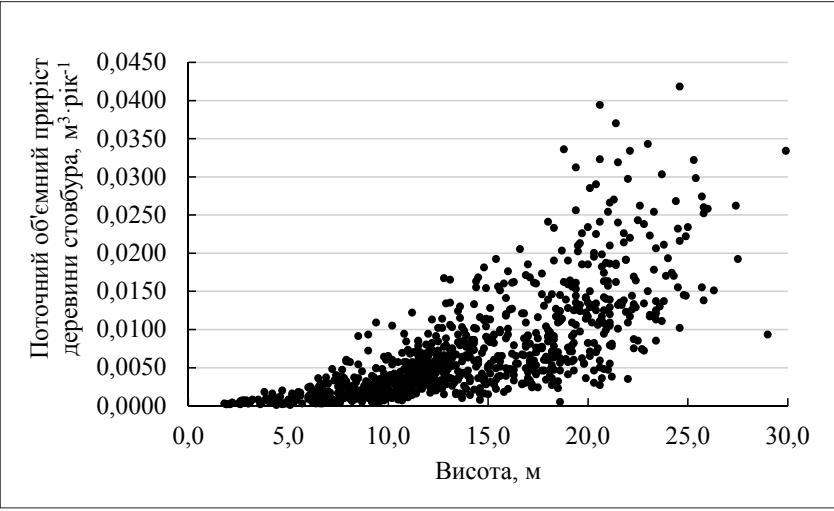

б)

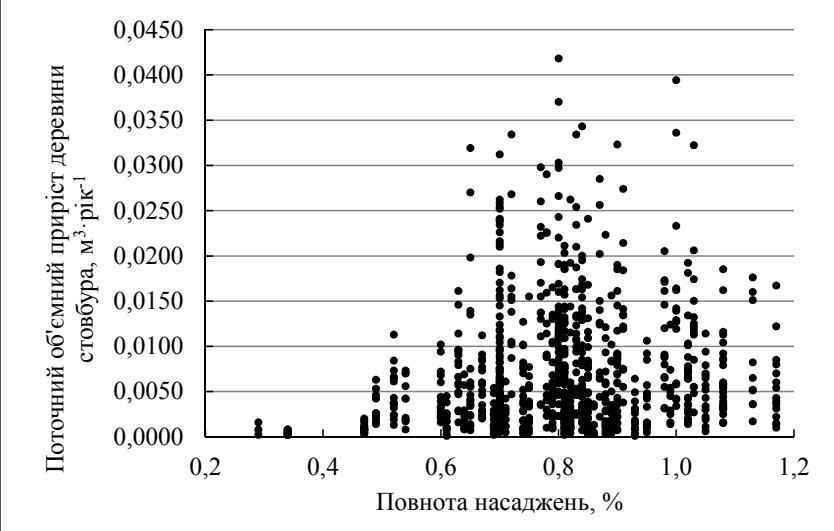

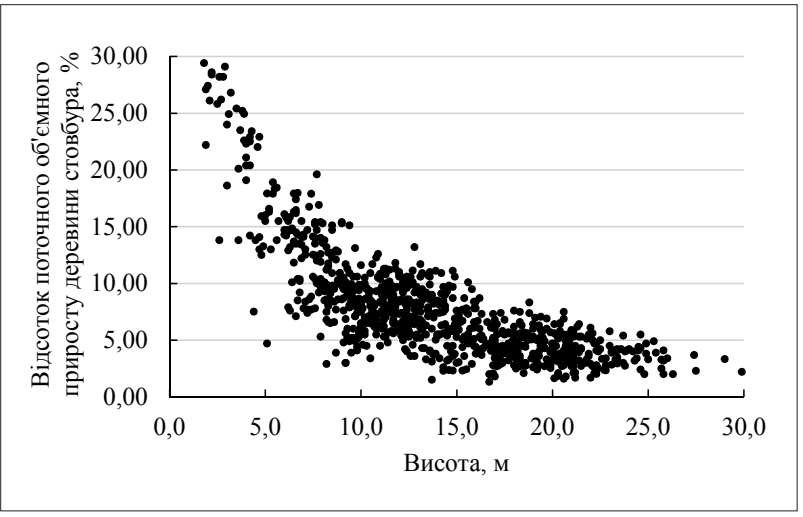

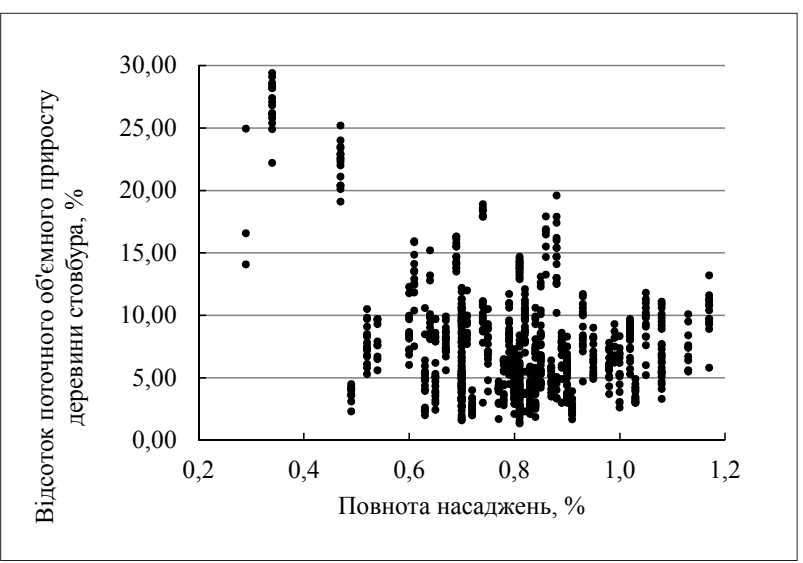

Рис. 3. Залежність абсолютного $\left(\mathrm{M}^{3} \cdot\right.$ рік $\left.^{-1}\right)$ та відносного (\%) поточного об'ємного приросту деревини стовбура від: а) висоти модельних дерев сосни звичайної; б) відносної повноти насаджень 
Моделі для оцінки показників, які використовували у розрахунках надземної первинної продукції дерев сосни звичайної

\begin{tabular}{|c|c|}
\hline 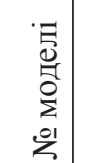 & Вид моделі \\
\hline
\end{tabular}

абсолютного поточного об'ємного приросту деревини стовбурів

\begin{tabular}{|c|c|c|}
\hline 1 & $z_{v}=a^{-1,593} \cdot d^{2,667} \cdot \exp (-5,775-25,619 / a)$ & 0,89 \\
\hline \multicolumn{3}{|c|}{$\begin{array}{c}\text { відносного поточного об’ємного приросту деревини } \\
\text { стовбурів }\end{array}$} \\
\hline 2 & $p_{v}=a^{-1,368} \cdot d^{0,115} \cdot \exp (6,332-2,372 / a)$ & 0,89 \\
\hline \multicolumn{3}{|c|}{ об’єму кори стовбурів дерев } \\
\hline 3 & $v_{k}=78,198 \cdot 10^{-5} \cdot d^{2,001}$ & 0,92 \\
\hline \multicolumn{3}{|c|}{ маси деревини гілок в абсолютно сухому стані } \\
\hline 4 & $m_{d}^{2 i n}=a^{1,375} \cdot d^{2,271} \cdot \exp (-11,343+46,189 / a)$ & 0,86 \\
\hline \multicolumn{3}{|c|}{ маси кори гілок в абсолютно сухому стані } \\
\hline 5 & $m_{k}^{2 i n}=0,017 \cdot a^{-0,754} \cdot d^{2,538}$ & 0,84 \\
\hline \multicolumn{3}{|c|}{ маси хвої в абсолютно сухому стані } \\
\hline 6 & $m_{x b}=0,081 \cdot a^{-0,986} \cdot d^{2,699}$ & 0,72 \\
\hline
\end{tabular}

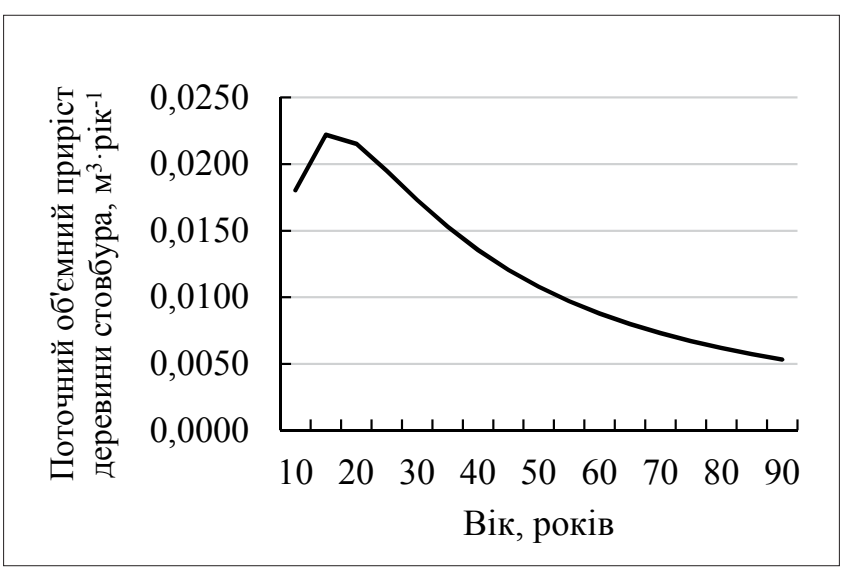

Рис. 4. Характер зміни абсолютного поточного об’ємного приросту деревини стовбурів дерев сосни звичайної залежно від віку та діаметра (за діаметра стовбура 20 см)

Ілюстрована зміна (див. рис. 4) абсолютного поточного об'ємного приросту деревини стовбурів дерев сосни звичайної підтверджує коректність вибраної моделі, адже абсолютний поточний об'ємний приріст до певного віку зростає i, досягнувши свого максимуму, з віком спадає. Вік дерев, в якому спостережено максимальний абсолютний поточний об’ємний приріст деревини стовбура, значною мірою залежить від деревного виду, походження і продуктивності деревостану, типу лісорослинних умов та лісорослинної зони, в якій вони ростуть (Анучин, 1982).

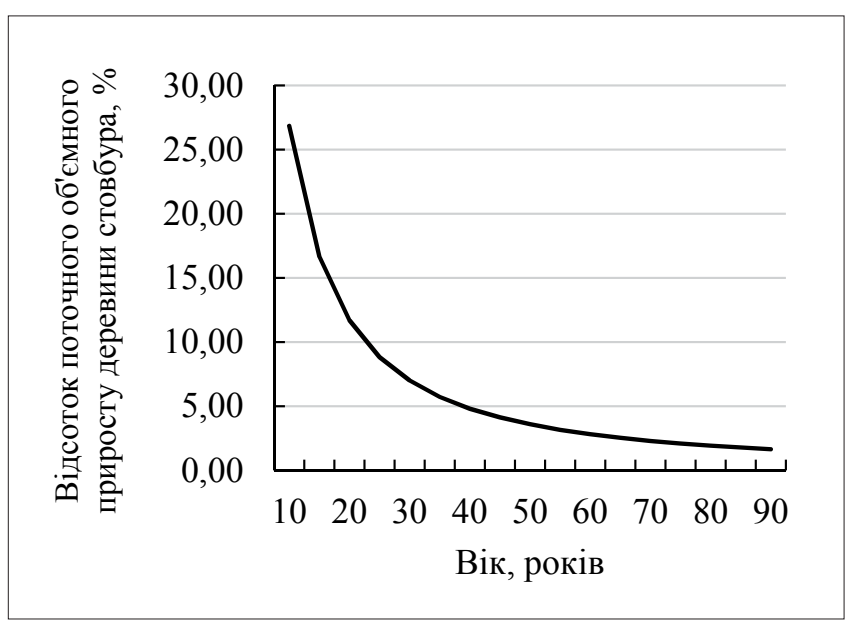

Рис. 5. Характер зміни відносного поточного об'ємного приросту деревини стовбурів дерев сосни звичайної залежно від віку та діаметра

(за діаметра стовбура 20 см)

Отриманий абсолютний поточний об'ємний приріст деревини стовбура (модель 1) порівнювали із нормативними даними поточного об'ємного приросту (Нормативно-справочные материалы..., 1987). Встановлено, що за діаметра 20 см та поточного приросту за діаметром $0,32 \mathrm{~cm}$, абсолютний поточний об'ємний приріст дерев сосни звичайної Східного Полісся України адекватний із нормативними даними поточного об'ємного приросту, й становить $0,0119 \mathrm{M}^{3}$.

Відображена на рис. 5 зміна відносного поточного об'ємного приросту деревини стовбурів дерев сосни звичайної також підтверджує коректність вибраної моделі (2), де відносний поточний об'ємний приріст спадає зі збільшенням віку при сталому діаметрі.

Під час порівняння відносного поточного об'ємного приросту встановлено, що за діаметра $20 \mathrm{~cm}$ та поточного приросту за діаметром $0,32 \mathrm{~cm}$, відносний поточний об'ємний приріст дерев сосни звичайної досліджуваного регіону адекватний із нормативними даними відносного поточного об'ємного приросту, який становить 4,9\% (Нормативно-справочные материалы..., 1987).

Розрахувавши за розробленою моделлю (1) абсолютний поточний об'ємний приріст деревини стовбурів дерев та використавши нормативне значення середньої щільності деревини стовбура сосни звичайної в абсолютно сухому стані (Лакида та ін., 2011), що становить 427 кг·( $\left(\mathrm{M}^{3}\right)^{-1}$, побудовано таблицю оцінювання первинної стовбурової продукції деревини дерев сосни звичайної, яка росте в типових лісорослинних умовах Східного Полісся України (фрагмент наведено в табл. 3).

Отже, показники первинної продукції стовбурової деревини сосни звичайної характерно змі- 
нюються в межах аналізованих аргументів (віку та діаметра). Зі збільшенням віку й діаметра первинна продукція деревини збільшується. За однакового діаметра зі збільшенням віку дерев первинна продукція стовбурової деревини збільшується лише до певного віку, а досягнувши максиму- му - зменшується. Зі збільшенням діаметра за однакового віку первинна продукція стовбурової деревини зростає. Встановлено, що у досліджуваному діапазоні віку та діаметра дерев, первинна продукція стовбурової деревини сосни змінюється від 0,1 до 14,5 кг· рік $^{-1}$.

Первинна продукція стовбурової деревини дерев сосни звичайної, кг·рік ${ }^{-1}$

Табличя 3

\begin{tabular}{|c|c|c|c|c|c|c|c|c|c|c|c|c|}
\hline \multirow{2}{*}{$\begin{array}{l}\text { Вік, } \\
\text { років }\end{array}$} & \multicolumn{12}{|c|}{ Діаметр стовбура дерева на висоті 1,3 м, см } \\
\hline & 4 & 6 & 8 & 10 & 12 & 14 & 16 & 18 & 20 & 22 & 24 & 26 \\
\hline 10 & 0,11 & 0,31 & 0,67 & 1,21 & & & & & & & & \\
\hline 15 & 0,13 & 0,38 & 0,82 & 1,49 & 2,43 & & & & & & & \\
\hline 20 & & 0,37 & 0,80 & 1,45 & 2,35 & 3,55 & & & & & & \\
\hline 25 & & 0,34 & 0,72 & 1,31 & 2,13 & 3,21 & & & & & & \\
\hline 30 & & & 0,64 & 1,16 & 1,89 & 2,85 & 4,07 & & & & & \\
\hline 35 & & & & 1,03 & 1,67 & 2,52 & 3,60 & 4,93 & & & & \\
\hline 40 & & & & & 1,48 & 2,23 & 3,19 & 4,36 & 5,78 & 7,45 & & \\
\hline 45 & & & & & 1,32 & 1,99 & 2,84 & 3,88 & 5,15 & 6,63 & 8,37 & \\
\hline 50 & & & & & & 1,78 & 2,54 & 3,48 & 4,61 & 5,94 & 7,49 & 9,27 \\
\hline 55 & & & & & & & 2,29 & 3,13 & 4,15 & 5,34 & 6,74 & 8,34 \\
\hline 60 & & & & & & & 2,07 & 2,83 & 3,75 & 4,84 & 6,10 & 7,55 \\
\hline 65 & & & & & & & & 2,58 & 3,41 & 4,40 & 5,55 & 6,87 \\
\hline 70 & & & & & & & & 2,36 & 3,12 & 4,02 & 5,07 & 6,28 \\
\hline 75 & & & & & & & & & 2,86 & 3,69 & 4,66 & 5,76 \\
\hline 80 & & & & & & & & & 2,64 & 3,40 & 4,29 & 5,31 \\
\hline 85 & & & & & & & & & 2,44 & 3,15 & 3,97 & 4,92 \\
\hline 90 & & & & & & & & & 2,27 & 2,92 & 3,69 & 4,56 \\
\hline
\end{tabular}

Первинну продукцію кори стовбурів дерев визначали через іiі об’єм, від якого брали відносну частку поточного об'ємного приросту деревини стовбура, умовно прийнявши, що приріст рівномірно відбувається у всіх компонентах фітомаси дерева, хоча і не $з$ однаковою інтенсивністю. Об'єм кори стовбура модельних дерев розраховували за різницею об’єму стовбура у корі та без кори, а потім здійснювали пошук математичної залежності об'єму кори стовбура від основних таксаційних показників дерев - віку, діаметра на висоті 1,3 м та висоти. Об'єм кори стовбурів сосни звичайної найкраще описує отримане регресійне рівняння 3 (див. табл. 2) від діаметра дерев на висоті 1,3 м.

Надземну первинну продукцію дерев розраховували як суму первинної продукції деревини стовбура, кори стовбура, деревини гілок, кори гілок та продукції хвої, відповідно до алгоритму іiї оцінювання (див. рис. 1) з використанням розроблених у процесі досліджень математичних моделей.

Для оцінювання первинної продукції компонентів крони, якими $є$ деревина, кора гілок та хвоя дерев (див. рис. 1), використовували визначені в процесі досліджень показники їхньої маси, об'єму, природної й базисної щільності деревини та кори гілок, а також відносний поточний приріст деревини стовбура за об'ємом.

Масу деревини гілок сосни звичайної розраховано за розробленою у процесі досліджень математичною моделлю 4 (див. табл. 2), вхідними параметрами до якої є вік та діаметр дерев $\left(\mathrm{R}^{2}=0,86\right)$. Розраховану за моделлю (4) масу деревини гілок переводили в іiї об'єм через показники природної щільності деревини гілок $\left(931 \kappa^{\cdot} \cdot\left(\mathrm{M}^{3}\right)^{-1}\right)$, яку взято iз нормативних даних (Лакида та ін., 2011).

Поточний об'ємний приріст деревини гілок, аналогічно як і кори стовбура, розраховували від об'єму деревини гілок за встановленою відносною часткою поточного приросту деревини стовбура, а первинну продукцію обчислювали через значення базисної щільності деревини гілок. За нормативними даними (Лакида та ін., 2011) базисна щільність деревини гілок сосни звичайної становить $396 \kappa \Gamma \cdot\left(\mathrm{M}^{3}\right)^{-1}$.

Показники маси кори гілок сосни також розраховано за розробленою в процесі досліджень математичною моделлю (5), вхідними параметрами якої $є$ вік і діаметр дерев. Встановлено зворотній 
зв'язок між корою гілок і віком дерев сосни звичайної $\left(\mathrm{R}^{2}=0,84\right)$.

Розраховану за моделлю (5) масу кори гілок сосни звичайної переводили в її об'єм через показники природної щільності, яка становить 993 кг·( $\left.\mathrm{M}^{3}\right)^{-1}$ (Лакида та ін., 2011). Поточний об’ємний приріст кори гілок сосни, аналогічно як і деревини гілок, розраховували від об'єму кори гілок за встановленою відносною часткою поточного приросту деревини стовбура, а первинну продукцію розраховували через значення базисної щільності кори гілок, яка становить 344 кг. $\left(\mathrm{м}^{3}\right)^{-1}$ (Лакида та ін., 2011). Первинну продукцію гілок сосни загалом склала сума продукції деревини та кори гілок.

Первинну продукцію хвої сосни становить лише хвоя першого року, масу якої із загальної маси хвої в процесі досліджень виокремлювали через ії відносну частку у деревній зелені. Оскільки, на закладених для досліджень ТПП хвою за віком не розподіляли, а визначали лише загальну масу хвої, то значення частки хвої різних років у деревній зелені сосни звичайної запозичили з роботи М.М. Петренка (2002), дослідження якого стосуються штучних соснових насаджень Полісся України. Використавши встановлені ним значення відносної частки хвої різних років, нами розроблено модель залежності відносної частки хвої першого року $\left(P_{x \in l}\right)$ від віку дерев:

$$
P_{x B 1}=100,889 \cdot a^{-0,197} \text {. }
$$

Зв'язок відносної частки хвої першого року сосни звичайної з віком дерев зворотній і помірний, але значущий на $5 \%$-му рівні при $\mathrm{R}^{2}=0,33$. Невисоке значення останнього показника можна пояснити недостатнім обсягом спостережень. Якісні показники хвої різних років М. М. Петренком (2002) досліджено лише на п'яти ТПП, на яких зрубано та детально обміряно тільки 30 МД, які росли в умовах свіжого субору, а їхній вік становив від 15 до 72 років. Дослідником також відзначено тенденцію зменшення відносної частки хвої першого року зі збільшенням віку насадження, що підтверджено отриманою нами моделлю.

Первинну продукцію надземної частини дерев сосни звичайної, які ростуть в типових лісорослинних умовах Східного Полісся України, склала сума продукції деревини та кори стовбура, деревини та кори гілок і продукція хвої першого року. Наведені дані (табл. 4) підтверджують, що первинна продукція надземної частини дерев сосни звичайної, подібно як і окремих компонентів надземної фітомаси дерев, зі збільшенням віку та діаметра, а також за однакового віку зі збільшенням діаметра дерев зростає; за однакового діаметра зі збільшенням віку дерев - спадає. Встановлено, що у типових лісорослинних умовах Східного Полісся України, середньовікове дерево сосни звичайної (50 років) у надземній частині може нагромаджувати 15,22 кг·рік-1 первинної продукції.

Первинна продукція надземної частини дерев сосни звичайної, кг·рік ${ }^{-1}$

Таблиия 4

\begin{tabular}{|c|c|c|c|c|c|c|c|c|c|c|c|c|}
\hline \multirow{2}{*}{$\begin{array}{l}\text { Вік, } \\
\text { років }\end{array}$} & \multicolumn{12}{|c|}{ Діаметр стовбура дерева на висоті 1,3 м, см } \\
\hline & 4 & 6 & 8 & 10 & 12 & 14 & 16 & 18 & 20 & 22 & 24 & 26 \\
\hline 10 & 0,48 & 1,34 & 2,81 & 5,00 & & & & & & & & \\
\hline 15 & 0,33 & 0,95 & 2,01 & 3,61 & 5,83 & & & & & & & \\
\hline 20 & & 0,76 & 1,63 & 2,92 & 4,71 & 7,09 & & & & & & \\
\hline 25 & & 0,64 & 1,34 & 2,43 & 3,92 & 5,90 & & & & & & \\
\hline 30 & & & 1,14 & 2,05 & 3,33 & 5,00 & 7,13 & & & & & \\
\hline 35 & & & & 1,77 & 2,87 & 4,30 & 6,14 & 8,39 & & & & \\
\hline 40 & & & & & 2,49 & 3,75 & 5,34 & 7,30 & 9,67 & 12,44 & & \\
\hline 45 & & & & & 2,20 & 3,30 & 4,71 & 6,44 & 8,53 & 10,97 & 13,83 & \\
\hline 50 & & & & & & 2,95 & 4,19 & 5,73 & 7,58 & 9,76 & 12,29 & 15,22 \\
\hline 55 & & & & & & & 3,77 & 5,14 & 6,81 & 8,76 & 11,04 & 13,64 \\
\hline 60 & & & & & & & 3,39 & 4,64 & 6,14 & 7,92 & 9,97 & 12,33 \\
\hline 65 & & & & & & & 1,04 & 4,23 & 5,59 & 7,20 & 9,07 & 11,22 \\
\hline 70 & & & & & & & & 3,87 & 5,11 & 6,58 & 8,30 & 10,27 \\
\hline 75 & & & & & & & & 1,21 & 4,71 & 6,06 & 7,64 & 9,43 \\
\hline 80 & & & & & & & & 1,12 & 4,34 & 5,59 & 7,04 & 8,72 \\
\hline 85 & & & & & & & & 1,04 & 4,02 & 5,19 & 6,53 & 8,09 \\
\hline 90 & & & & & & & & & 3,75 & 4,82 & 6,09 & 7,53 \\
\hline
\end{tabular}


На сьогодні немає нормативів оцінки первинної продукції надземної частини дерев, розроблених подібним способом для сосни звичайної в умовах Східного Полісся України. У зв'язку з цим, порівнювали результати (рис. 6) лише первинної продукції стовбурової деревини сосни звичайної 3 аналогічною первинною продукцією деревини, визначеною шляхом множення нормативних значень абсолютного поточного об'ємного приросту культур сосни (Нормативно-справочные материалы..., 1987) на нормативний показник базисної щільності деревини сосни звичайної (Лакида та ін., 2011), який становить 427 кг·( $\left(\mathrm{M}^{3}\right)^{-1}$.

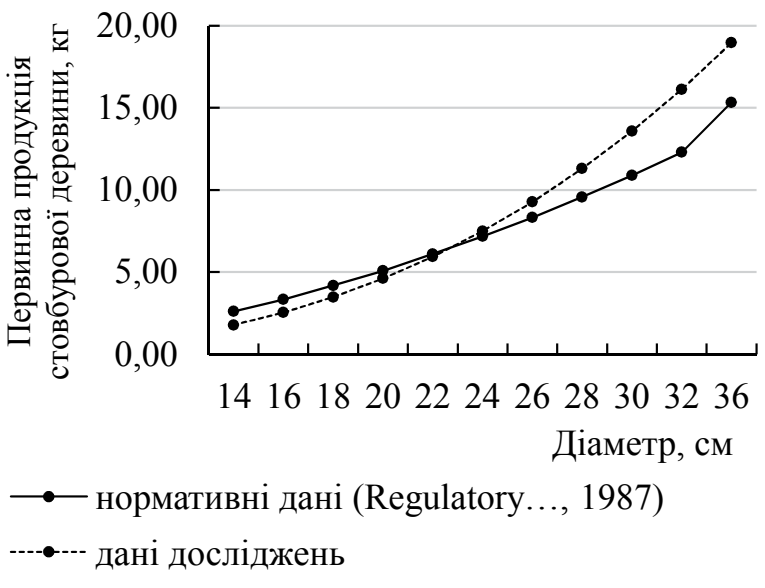

Рис. 6. Порівняння визначеної первинної продукції стовбурової деревини сосни звичайної за даними досліджень з отриманою за нормативними даними

За результатами порівняння, первинна продукція стовбурової деревини сосни звичайної, визначеної через поточний об'ємний приріст стовбурів культур сосни лісів України i Молдавії (Нормативносправочные материалы..., 1987) для різних значень діаметра за сталого поточного приросту за діаметром 0,32 см, виявилась досить близькою до аналогічних значень первинної продукції стовбурової деревини, отриманою за даними досліджень у Східному Поліссі України. Встановлено, що відповідно до порівнюваних значень, в низьких ступенях товщини (приблизно до 22 см) значення первинної продукції стовбурової деревини сосни звичайної, отримані за результатами досліджень, є дещо нижчими, а зі збільшенням діаметра ( 24 см і більше) - дещо вищими. Відмінність отриманих результатів, насамперед, можна пояснити відмінністю в регіонах досліджень та представленістю дослідних даних, якими описано порівнювані сукупності значень.

Висновки. Статистичний аналіз і виявлені закономірності розподілу досліджуваних таксаційних показників модельних дерев сосни звичайної показали їхню значну мінливість навіть за значної кількості спостережень (900 МД). 3'ясовано, що нормальним розподілом значень характеризуються лише показники віку, діаметра, висоти дерев та повноти насаджень, в яких вони росли. Відрізняються від нормального розподілу показники об' $є м у$ (стовбура у корі, без кори, кори, поточного приросту), фітомаси гілок у корі, деревини та кори гілок, а також хвої в абсолютно сухому стані. Значно знижують мінливість абсолютних значень вказаних величин їхні натуральні логарифми, що дає змогу забезпечити адекватність і коректність побудованих на їхній основі математичних моделей.

За допомогою кореляційного аналізу виявлено наявність різної тісноти зв'язку (від помірного $-0,31<r<-0,50$, до дуже високого; $r>0,91)$ майже між усіма досліджуваними показниками модельних дерев сосни звичайної. Слабким $(0,11<r<0,30)$ виявився зв'язок з повнотою насаджень, а також відносної частки поточного об'ємного приросту з показниками компонентів фітомаси крони дерев.

У розрахованих моделей абсолютного і відносного поточного об'ємного приростів деревини стовбурів, об'єму кори стовбурів, маси деревини, кори гілок, маси хвої в абсолютно сухому стані та відносної частки хвої першого року оцінювані величини мають прямий зв'язок 3 діаметром дерев, а з віком - зворотній, окрім маси деревини гілок, для якої він $\epsilon$ прямим. Коефіцієнти детермінації математичних моделей знаходяться у проміжку від 0,72 до 0,92 , а для відносної частки хвої першого року становить 0,33 , будучи значущим на $5 \%$-му рівні.

Встановлено, що зі збільшенням віку й діаметра первинна стовбурова продукція деревини сосни звичайної збільшується. При однаковому діаметрі зі збільшенням віку дерев, аналогічно як i абсолютний поточний об'ємний приріст деревини стовбурів, первинна продукція стовбурової деревини збільшується лише до певного віку, а досягнувши максимуму - зменшується. Зі збільшенням діаметра за однакового віку первинна продукція стовбурової деревини зростає. У досліджуваному віковому діапазоні та діаметра дерев, первинна продукція стовбурової деревини сосни звичайної змінюється від 0,1 до 14,5 кг $\cdot$ рік $^{-1}$.

Первинна продукція надземної частини дерев сосни звичайної, подібно до окремих компонентів надземної фітомаси дерев, зі збільшенням віку та діаметра, а також за однакового віку зі збільшенням діаметра дерев зростає, а за однакового діаметра зі збільшенням віку дерев - спадає. У типових лісорослинних умовах Східного Полісся середньовікове дерево сосни звичайної в надземній частині може нагромаджувати 15,22 кг рік $^{-1}$ первинної продукції.

\section{Список літератури}

Анучин Н.П. (1982). Лесная таксация. Москва: Лесная промышленность [Anuchin, N. P. (1982). Forest assessment. Moscow: Forest Industry] (in Russian)

Білоус А.М., Миронюк В.В., Мацала М.С., Дячук П.П. (2018). Оцінювання чистої первинної продукції в лісах Українського Полісся. Цілі сталого розвитку третього тисячоліття: 
виклики для університетів наук про життя: матеріали міжнарод. наук.-практ. конф., м. Київ: НУБіП України. Т. 2. С. 23-24 [Belous, А. М., Муronyuk, V. V., Matsala, M. S.\& Dyachuk, P. P. (2018). Estimation of net primary products in the forests of Ukrainian Polissya. The goals of sustainable development of the third millennium: challenges for universities of life sciences. Proceedings of the International Scientific and Practical Conference, 23-24. Kyiv: National University of Life and Environmental Sciences of Ukraine of Ukraine, Vol. 2. 23-24. https://nubip.edu.ua/sites/default/files/u169/ tom_2_na_sayt_0.pdf] (in Ukrainian)

Ворнов М.П., Усольцев В.А., Часовских В.П. (2010). Исследование методов и разработка информационной системь определения $u$ картирования депонируемого лесами углерода в среде Natural. Екатеринбург: Уральский государств. лесотехн. ун-т. 160 с. [Vornov, M.P., Usoltsev, V. A. \& Chasovskikh, V. P. (2010). Research of methods and development of the information system of definition and mapping of the carbon deposited by forests in the Natural environment: Ekaterinburg: Ural State Forestry University] (in Russian)

Горошко М.П., Миклуш С. І., Хомюк П.Г. (2004). Біометрія. Львів: Камула. 236 с. [Goroshko, M.P., Myklush, S.I., \& Khomiuk, P.G. (2004). Biometrics. Lviv : Kamula] (in Ukrainian)

Кнорре А.А., Кирдянов А.В., Круглов В.Б., Силкин П.П. (2005). Исспользование измерений радиального прироста для оценки годичной продукичи древостоев. Вестник КрасГУ, 5, С. 7478 [Knorre, A.A., Kirdyanov, A. V., Kruglov, V. B., \& Silkin, P. P. (2005). Using measurements of radial growth to estimate the annual production of stands. Bulletin of KrasSU, 5, 74-78. http://forest.akadem.ru/Articles/05/ knorre_1.pdf] (in Russian)

Лакида П.І. (2002). Фітомаса лісів України: Тернопіль: Збруч. 256 с. [Lakyda, P. I. (2002). The Forests phytomass of Ukraine: Ternopil: Zbruch] (in Ukrainian)

Лакида П.І., Василишин Р.Д., Блищик В.І., Терентьєв А. Ю., Лакида І. П., Домашовець Г. С. ... Стратій Н.В. (2016). Хвойні деревостани Украӥни: фітомаса та експериментальні дані: КорсуньШевченківський: ФОП Гавришенко В.М. 480 с. [Lakyda, P.I., Vasylyshyn, R.D., Blyshchyk, V.I., Terentiev, A.Yu., Lakyda, I.P., Domashovets, G. S. ... Stratiy, N. V. (2016). Coniferous stands of Ukraine: phytomass and experimental data. Korsun-Shevchenkivskyi: FOP Gavrishenko V.M.] (in Ukrainian)

Лакида П.І., Василишин Р.Д., Лащенко А.Г., Терентьєв А. Ю., Матушевич Л. М., Блищик В. І. ... Білоус А. М. (2011). Нормативи оцінки компонентів надземної фітомаси дерев головних лісотвірних порід Украӥни : [монографія]. Київ: Видавничий дім «ЕКО-інформ». 192 с. [Lakyda, P. I., Vasylyshyn, R.D., Lashchenko, A.G., Terentiev, A. Yu., Matushevych, L.M., Blyshchyk, V.I... Belous, A.M. (2011). Standards for assessing the components of aboveg- round phytomass of trees of the main forest forming species of Ukraine. Kyiv: ECO-Inform Publishing House] (in Ukrainian)

Лакида П.І., Василишин Р.Д., Матушевич Л.М., Бала О.П., Лакида І.П. (2017). Дослідження біопродукційних процесів деревостанів України в контексті екологічного збалансування довкілля. Ліси Східнӧ̈ Свропи у світі, щуо змінюється: матеріали міжнарод. наук.-практ. конф., присвячені 120-річчю НУБІП України та 80-річчю академіка Лісівничої академії наук України та Свразійської академії наук, професора А. 3. Швиденка, м. Київ, 27-30 вересня 2017 р. Київ, 2017. С. 73-74 [Lakyda, P. I., Vasylyshyn, R. D., Matushevych, L. M., Bala, O.P., \& Lakyda, I.P. (2017). Research of bioproductive processes of stands in Ukraine in the context of ecological balancing of the environment. Forests of Eastern Europe in a Changing World: International Scientific and Practical Conference Dedicated to the 120th Anniversary of the National University of Life and Environmental Sciences of Ukraine and the 80th Anniversary of Academician of the Forestry Academy of Sciences of Ukraine and Eurasian Academy of Sciences, Honorary Professor of the National University of Life and Environmental Sciences of Ukraine Shvidenko A.Z., 73-74. Kyiv: NULES. http://dspace.wunu.edu.ua/bitstream/316497/250 73/1/126_T_17.pdf] (in Ukrainian)

Лакида П. І., Матушевич Л. М. (2012). До методики оцінки біотичної продукції компонентів крони дерев. Ліс, довкілля, технології: наука та інновацї: матеріали міжнарод. наук.-практ. конф., м. Київ, 29 березня 2012 р. Київ, с. 145-146. [Маtushevych, L. M., \& Lakyda, P. I. (2012). To the method of evaluation of biotic products of tree crown components. In Forest, environment, technologies: science and innovations: International scientific-practical conference. Kyiv, 145-146. Kyiv, Ukraine: National University of Life and Environmental Sciences of Ukraine] (in Ukrainian)

Лакида П. І., Матушевич Л. М. (2015). До методики оцінки індексу листкової поверхні насаджень. Біоресурси лісових та урбанізованих екосистем: відтворення, збереження і раціональне використання: міжнарод. наук.-практ. конф., м. Київ, 2324 квітня 2015 р. Київ, с. 49-50 [Lakyda, P. I., \& Matushevych, L. M. (2015). To the method of estimating the index of the leaf surface of plantations. In Bioresources of forest and urban ecosystems: reproduction, conservation and rational use: International scientific-practical conference, 23-24. Kyiv, Ukraine: National University of Life and Environmental Sciences of Ukraine] (in Ukrainian)

Лакида П.ІІ, Матушевич Л.М. (2006). Фітомаса березових лісостанів Українського Полісся: Київ : ННЦ IAE. 228 c. [Lakyda, P. I., \& Matushevych, L. M. (2006). Phytomass of birch forests of Ukrainian Polissya. Kyiv: NSC IAE] (in Ukrainian)

Лакида П.І., Маушевич Л.М., Блищик В. І. (2018). Методика оцінювання продукції гілок крони дерев: [авторське свідоцтво]. Свідоцтво про реєстрацію авторського права на твір № 83023 від 21.11.2018; заявник та власник Національний 
університет біоресурсів і природокористування України; заявлено 21.09.2018 [Lakyda, P. I., Matushevych, L.M., \& Blyshchyk, V.I. (2018). Methods for evaluating the products of tree branches: [author's certificate]. Certificate of copyright registration for the work № 83023 dated 11/21/2018; applicant and owner National University of Life and Environmental Sciences of Ukraine; declared 21.09.2018] (in Ukrainian)

Лакида П. І., Матушевич Л. М., Блищик В. І. (2012). Методологічні особливості оцінки біотичної продукції компонентів крони дерев. Науковий вісник Національного університету біоресурсів i природокористування України. Серія: Лісівництвво та декоративне садівництво, 171(2), C. 54-60 [Lakyda, P.I., Matushevych, L.M., \& Blyshchyk, V.I. (2012). Methodological features of biotic products evaluation of tree crown components. Scientific Bulletin of the National University of Life and Environmental Sciences of Ukraine. Series: Forestry and ornamental horticulture, 171(2), 54-60. Retrieved from http://www.irbis-nbuv.gov.ua/cgi-bin/irbis nbuv/cgiirbis 64.exe?I21DBN=LINK\&P21DBN=UJRN $\quad \& Z 21 \mathrm{I}$ $\mathrm{D}=\& \mathrm{~S} 21 \mathrm{REF}=10 \& \mathrm{~S} 21 \mathrm{CNR}=20 \& \mathrm{~S} 21 \mathrm{STN}=1 \& \mathrm{~S} 21 \mathrm{FM}$ $\mathrm{T}=\mathrm{ASP} \_$meta\&C21COM=S\&2_S21P03 $=\mathrm{FILA}=\& 2$ S21STR=nvnau_lis_2012_171(2)_9] (in Ukrainian)

Лакида П.І., Матушевич Л.М., Ловинська В.М. (2015). Особливості методики оцінки бічної поверхні хвої. Біоресурси лісових та урбанізованих екосистем: відтворення, збереження $i$ раціональне використання: міжнарод. наук.-практ. конф., м. Київ, 23-24 квітня 2015 р. Київ, с. 3940. [Lakyda, P. I., Matushevych, L. M., \& Lovynska, V. M. (2015). Features of the method of assessing the lateral surface of the needles. In Bioresources of forest and urban ecosystems: reproduction, conservation and rational use: International scientific-practical conference, 23-24. Kyiv, Ukraine: National University of Life and Environmental Sciences of Ukraine] (in Ukrainian)

Матушевич Л.М., Лакида П.І. (2014). Індекс площі листкової поверхні дубових насаджень Східного Полісся України. Наукові праиі Лісівничої академії наук України, 12, 148-153. [Matushevych, L. M. \& Lakyda, P.I. (2014). Index of leaf surface area of oak plantations in Eastern Polissya of Ukraine. Proceedings of the Forestry Academy of Sciences of Ukraine, 12, 148-153. Retrieved from http://nbuv. gov.ua/UJRN/Nplanu_2014_12_22] (in Ukrainian)

Матушевич Л.М., Лакида П.І. (2018). Методика оцінки індексу площі листкової поверхні насаджень: [авторське свідоцтво]. Свідоцтвво про реєстрачію авторського права на твір №82936 від 19.11.2018; заявник та власник Наџіональний університет біоресурсів і природокористування України; заявлено 21.09.2018 [Matushevych, L.M., \& Lakyda, P. I. (2018). Methods for estimating the index of the leaf surface area of plantations: [author's certificate]. Certificate of registration of copyright to the work №82936 dated 19.11.2018; applicant and owner National University of Life and Environmental Sciences of Ukraine; declared 21.09.2018] (in Ukrainian)
М'якушко В. К. (1972). Первинна біологічна продуктивність соснових лісів Украӥнського Полісся. Укр. ботан. журн., 29(3), C. 328-339 [Myakushko, V.K. (1972). Net primary biological productivity of pine forests of Ukrainian Polissya. Ukrainian Botanical Journal, 29(3), 328-339] (in Ukrainian)

Никитин К.Е., Швиденко А.З. (1978). Методы и техника обработки лесоводственной информации. Москва: Лесная промышленность, 271 с. [Nikitin, K.E., \& Shvidenko, A.Z. (1978). Methods and techniques of forestry information processing. Moscow: Forest Industry] (in Russian)

Ольчев А. В. (2016). Модельный подход к определению валовой и нетто первичной продукции лесных экосистем по величине поглощенной фотосинтетически активной радиации. Компьютерные исследования и моделирование, 8(2), 345-353 [Olchev, A. V. (2016). Model approach to the determination of gross and net primary production of forest ecosystems by the amount of absorbed photosynthetically active radiation. Computer research and modeling, 8(2), 345-353. https://doi.org/10.20537/2076-7633-2016-8-2-345-353] (in Russian)

Петренко М.М. (2002). Динаміка фітомаси та депонованого вуглецю штучних насаджень сосни Полісся України: дис. ... канд. с.-г. наук: 06.03.02. Національний аграрний університет, Київ, 136 с. [Petrenko, M. M. (2002). Dynamics of phytomass and deposited carbon of artificial pine plantations of Ukrainian Polissya. (Doctoral dissertation, Author's abstract, National Agrarian University, Kyiv, Ukraine). Retrieved from: http://irb.nubip.edu.ua/cgi-bin/irbis64r_14/cgiirbis_64.ex $\mathrm{e} ? \mathrm{LNG}=\mathrm{en} \& \mathrm{C} 21 \mathrm{COM}=\mathrm{S} \& \mathrm{I} 21 \mathrm{DBN}=\overline{\mathrm{DA}} \& \mathrm{P} 21 \mathrm{DBN}=\mathrm{DA}$ $\& S 21 F M T=$ infow_wh $\&$ S2 $1 \mathrm{ALL}=\% 3 \mathrm{C} . \% 3 \mathrm{EK} \% 3 \mathrm{D} \% \mathrm{D}$ $0 \% 9 \mathrm{~B} \% \mathrm{D} 0 \% 86 \% \mathrm{D} 0 \% \mathrm{~A} 1 \% \mathrm{D} 0 \% 9 \mathrm{E} \% \mathrm{D} 0 \% 92 \% \mathrm{D} 0 \% 90 \$$ $\% 3 \mathrm{C} . \% 3 \mathrm{E} \& \mathrm{Z} 21 \mathrm{ID}=\& \mathrm{~S} 21 \mathrm{SRW}=\& \mathrm{~S} 21 \mathrm{SRD}=\& \mathrm{~S} 21 \mathrm{STN}$ $=1 \& \mathrm{~S} 21 \mathrm{REF}=10 \& \mathrm{~S} 21 \mathrm{CNR}=30 \& \mathrm{FT} \_\mathrm{REQUEST}=\& \mathrm{FT}$ PREFIX $=$ ] (in Ukrainian)

Свирежев Ю.М. (1981). Моделирование окружающей среды и проблема недостатка информации. В кн.: Математические модели в экологии и генетике. Москва: Наука, с. 17-22 [Svirezhev, Yu. M. (1981). Environmental modeling and the problem of lack of information. In Mathematical models in ecology and genetics (pp. 17-22). Moscow: Science. Retrieved from: https://search.rsl.ru/ru/searc $\mathrm{h} \# \mathrm{yf}=1981 \& \mathrm{q}=\% \mathrm{D} 0 \% \mathrm{~A} 1 \% \mathrm{D} 0 \% \mathrm{~B} 2 \% \mathrm{D} 0 \% \mathrm{~B} 8 \% \mathrm{D} 1 \%$ $80 \% \mathrm{D} 0 \% \mathrm{~B} 5 \% \mathrm{D} 0 \% \mathrm{~B} 6 \% \mathrm{D} 0 \% \mathrm{~B} 5 \% \mathrm{D} 0 \% \mathrm{~B} 2 \% 2 \mathrm{C} \% 20$ $\% \mathrm{D} 0 \% \mathrm{AE} \% \mathrm{D} 1 \% 80 \% \mathrm{D} 0 \% \mathrm{~B} 8 \% \mathrm{D} 0 \% \mathrm{~B} 9 \% 20 \% \mathrm{D} 0 \% 9 \mathrm{C} \%$ D0\%B8\%D1\%85\%D0\%B0\%D0\%B9\%D0\%BB\%D0\%B $\mathrm{E} \% \mathrm{D} 0 \% \mathrm{~B} 2 \% \mathrm{D} 0 \% \mathrm{~B} 8 \% \mathrm{D} 1 \% 87]$ (in Russian)

Усольцев В.А. (2007). Биологическая продуктивность лесов Северной Евразии: методь, база данных и ее приложения. Екатеринбург: УрО РАН. 636 c. [Usoltsev, V.A. (2007). Biological productivity of forests of Northern Eurasia: methods, database and its applications. Yekaterinburg: UrO RAN. Retrieved from: https://www.twirpx.com/file/1593367/] (in Russian)

Усольцев В.А. (2010). Фитомасса и первичная продукиия лесов Евразии. Екатеренбург: УрО 
PAH. 570 c. [Usoltsev, V.A. (2010). Live biomass and net primary products of Eurasian forests. Yekaterinburg: UrO RAS. Retrieved from: https://elar.usfeu.ru/handle/123456789/2606] (in Russian)

Усольцев В.А., Залесов С.В. (2005). Методы определения биологической продуктивности насаждений.. Екатиренбург: Уральский гос. лесотех. ун-т. 147 c. [Usoltsev, V.A., \& Zalesov, S.V. (2005). Methods for determining the biological productivity of plantations. Yekaterinburg: Ural State Forestry University. Retrieved from https://www.twirpx.com/ file/1593367/] (in Russian)

Уткин А.И. (1970). Исследования по первичной биологической продуктивности лесов в СССР. Лесоведение, 3, 58-89. [Utkin, A.I. (1970). Research on the primary biological productivity of forests in the USSR. Forestry, 3, 58-89] (in Russian)

Уткин А.И. (1982). Методика исследований первичной биологической продуктивности лесов. В кн.: Биологическая продуктивность Поволжья. Москва: Наука. С. 59-72. [Utkin, А. I. (1982). Methods of research of primary biological productivity of forests. In Biological productivity of the Volga region (pp. 59-72). Moscow: Science] (in Russian)

Уткин А.И., Замолодчиков Д.Г., Пряжников А.А. (2003). Методы определения депонирования углерода фитомассы и нетто-продуктивности лесов (на примере республики Беларусь). Лесоведение, 1, 48-57. [Utkin, A. I., Zamolodchikov, D. G. \& Pryazhnikov, A.A. (2003). Methods for determining the carbon deposition of live biomass and net productivity of forests (on the example of the Republic of Belarus). Forestry, 1, 48-57. Retrieved from http://old.cepl.rssi.ru/publications/ pub_lab1/utkin $\% 2003 \% 20$ metody $\% 20$ opredelenia $\% 20$ deponirovania\%20na\%20primere\%20Belarusi.pdf] (in Russian)

Швиденко А.3., Лакида П.І., Василишин Р.Д. (2015). Проблеми адаптації українських лісів до змін клімату. Виклики XXI століття та їхне вирішення у лісовому комплексі й довкіллі: міжнарод. наук.-практ. конф., Національний університет біоресурсів і природокористування України, м. Київ, 7-9 жовтня 2015 р. Київ, с. 5354 [Shvidenko, A.Z., Lakyda, P. I., \& Vasylyshyn, R.D. (2015). Problems of adaptation of Ukrainian forests to climate change. In Challenges of the XXI century and their solution in the forest complex and environment: International scientific-practical conference, 53-54. Kyiv, National University of Life and Environmental Sciences of Ukraine] (in Ukrainian)

Швиденко А.З., Лакида П.І., Щепащенко Д.Г., Василишин Р.Д., Марчук Ю.М. (2014). Вуглеиь, клімат та землекористування в Украӥні: лісовий сектор. Корсунь-Шевченківський: ФОП Гавришенко В.М. 283 с. [Shvidenko, A.Z., Lakyda, P.I., Shchepashchenko, D.G., Vasylyshyn, R.D. \& Marchuk, Yu. M. (2014). Carbon, climate and land use in Ukraine: forest sector. Korsun-Shevchenkivsky: FOP Gavrishenko V.M.] (in Ukrainian)
Швиденко А. 3., Нильссон С., Столбовой В.С., Рожков В.А., Глюк М. (2001). Опыт агрегированной оценки основных показателей биопродукционного процесса и углеродного бюджета наземных экосистем России. Нетто-первичная продукция екосистем. Экология, 2, 83-90 [Shvidenko, A.Z., Nilsson, S., Stolbovoy, V.S., Rozhkov, V.A. \& Gluk, M. (2001). The experience of aggregate assessment of the main indicators of the bioproduction process and the carbon budget of terrestrial ecosystems in Russia. 2. Net primary products of ecosystems. Ecology. No 2. 83-90. Retrieved from: http://irbis.sstu.ru/cgibin/irbis64r_15/cgiirbis_64. exe? $\mathrm{LNG}=\& \mathrm{Z} 21 \mathrm{ID}=\& \mathrm{I} 21 \mathrm{DBN}=\mathrm{MARS} \& \mathrm{P} 21 \mathrm{DBN}=\mathrm{M}$ ARS \&S21STN $=1 \& S 21$ REF $=\& S 21 \mathrm{FMT}=$ fullwebr $\&$ C 2 $1 \mathrm{COM}=\mathrm{S} \& \mathrm{~S} 21 \mathrm{CNR}=20 \& \mathrm{~S} 21 \mathrm{P} 01=0 \& \mathrm{~S} 21 \mathrm{P} 02=1 \& \mathrm{~S} 21$ $\mathrm{P} 03=\mathrm{A}=\& \mathrm{~S} 21 \mathrm{STR}=\% \mathrm{D} 0 \% \mathrm{~A} 8 \% \mathrm{D} 0 \% \mathrm{~B} 2 \% \mathrm{D} 0 \% \mathrm{~B} 8 \% \mathrm{D} 0$ $\% \mathrm{~B} 4 \% \mathrm{D} 0 \% \mathrm{~B} 5 \% \mathrm{D} 0 \% \mathrm{BD} \% \mathrm{D} 0 \% \mathrm{BA} \% \mathrm{D} 0 \% \mathrm{BE} \% 2 \mathrm{C} \% 20$ $\% \mathrm{D} 0 \% 90 \% 2 \mathrm{E} \% 20 \% \mathrm{D} 0 \% 97 \% 2 \mathrm{E}]$ (in Russian)

Швиденко А.З., Строчинский А.А., Савич Ю.Н., Кашпор С.Н., Поляков В.К., Лакида П. И. ... Возняк В.К. (1987). Нормативно-справочные материаль для таксачии лесов Украины и Молдавии: под. ред. А. З. Швиденко и др. Киев: Урожай. 560 с. [Shvidenko, A.Z., Strochinsky, A. A., Savich, Yu. N., Kashpor, S. N., Polyakov, V.K., Lakyda, P.I.... Wozniak, V.K. (1987). Regulatory and reference materials for the assessment of forests of Ukraine and Moldova. A.Z. Shvidenko et al. Kyiv: Harvest] (in Ukrainian)

Швиденко А.З., Щепащенко Д.Г., Ваганов Е.А., Нильсон С. (2008). Чистая первичная продукиия лесных экосистем России: новая оценка. Доклады Академии Наук, 421(6), 1-5 [Shvidenko, A.Z., Shchepashchenko, D. G., Vaganov, E.A. \& Nilsson, S. (2008). Net primary production of forest ecosystems in Russia: a new assessment. Reports of the Academy of Sciences, 421(6), 1-5. Retrieved from: http://naukarus. com/chistaya-pervichnaya-produktsiya-lesnyh-ekosistemrossii-novaya-otsenka] (in Russian)

Cannell, M. G. R. (1989). Physiological basis of wood production: a review. Scand. J. For. Res., 4(4), 459490. Retrieved from: https://www.tandfonline.com/ doi/pdf $/ 10.1080 / 02827588909382582$ ?needAccess= true

Clark, D.A., Brown, S., Kicklighter, D.W., Chambers J. Q., Thomlinson J. R., \& Ni, J. (2001). Measuring net primary production in forests: concepts and field methods. Ecological Applications, 11(2), 356370. https://doi.org/10.2307/3060894

Cramer, W., Kicklighter, D.W. \& Bondeau, A., Moore I. B., Churkina, G., Nemry, B., Ruimy, A., \& Schloss, A.L. (1999). Comparing global models of terrestrial net primary productivity (NPP): Overview and key results. Global Change Biology, 5, 1-15. https://doi.org/10.1046/j.1365-2486.1999.00009.x

Gower, S.T., Krankina, O., Olson, R.J., Apps, M., Linder, S., \& Wang, C. (2001). Net primary production and carbon allocation patterns of boreal forest ecosystems. Ecological Applications, 11(5), 1395-1411. https://doi.org/10.1890/1051-0761(2001)011[1395: NPPACA]2.0.CO;2 
Jenkins, J. C., Chojnacky, D.C., Heath, L.S. \& Birdsey, R.A. (2004). Comprehensive database of diameter-based biomass regressions for North American tree species. USDA Forest Service. Northeastern Research Station. GTR NE-319. Retrieved from: http://www.fs.fed.us/neT

Lieth, H. (1975). Historical survey of primary productivity research. Ecological studies: Analysis and synthesis, 14, 7-16. Retrieved from https://link.springer. com/chapter/10.1007/978-3-642-80913-2_2

Tateno, R., Hishi, T., \& Takeda, H. (2004). Above- and belowground biomass and net primary production in a cool-temperate deciduous forest in relation to topographical changes in soil nitrogen. Forest Ecology and Management, 193, 297-306. Retrieved from: https://www.sciencedirect.com/science/article/abs/ pii/S037811270300522X?via\%3Dihub

Vogt, K.A., Grier, C. C. \& Vogt, D. J. (1986). Production, turnover and nutrient dynamics of above- and belowground detritus of world forests. Advance Ecological Restoration, 15, 303-377. https://doi. org/10.1016/S0065-2504(08)60122-1

\section{Modeling of the aboveground part of Scots pine trees components primary productions at the Eastern Polissya of Ukraine}

\author{
L. Matushevych¹, P. Lakyda²
}

The net primary productions of the aboveground phytomass components (tree trunks and crowns) are estimated for Scots pine trees, which grow mainly in pure and mixed (admixture from 1 to 3 units) pine plantations of artificial origin of the Eastern Polissya of Ukraine. Plantations are characterized as highly productive (II, I, I and above classes of quality), medium and high-density stands whcih grow in fresh forests $\left(A_{2}\right)$, subors $\left(B_{2}\right)$ and sogruds $\left(C_{2}\right) .80$ temporary test plots (TTP) used, which were planted in pine stands of Sumy (36 TTP) and Chernihiv (44 TTP) regions, where

Liubov Matushevych - Corresponding Member of the Forestry Academy of Sciences of Ukraine, Candidate of Agricultural Sciences, Associate Professor of the Department of Forest Mensuration and Forest Management. National University of Life and Environmental Sciences of Ukraine, Heroiv Oborony str., 15, Kyiv, 03041, Ukraine. Tel: 044-527-85-23; +38-067-944-8275. Email: Matushevych@nubip.edu.ua ORCID: https://orcid. org/0000-0001-7282-3215

Petro Lakyda - full Member of the Forestry Academy of Sciences of Ukraine, First Vice President of FAS of Ukraine, Professor, Doctor of Agricultural Sciences, Director of the Educational and Scientific Institute of Forestry and Landscape-Park Management. National University of Life and Environmental Sciences of Ukraine, Heroiv Oborony str., 15, Kyiv, 03041, Ukraine. Tel: 044-527-85-28; +38067-462-80-43. Email: lakyda@nubip.edu.ua ORCID: https:// orcid.org/0000-0003-3639-2969
900 model trees (MT) of Scots pine were cut down and measured, of which $226 \mathrm{MT}$ with fractional assessment of aboveground phytomass components and 674 MT assessment of crown phytomass. Measurement of models and calculations of aboveground phytomass components of Scots pine trees net primary productions was performed using improved applicable methods and developed algorithm.

The set of values of the experimental material in natural quantities is characterized by the normal distribution of values by age, diameter, and height of trees and relative density of stands. The closeness of the connection exists between all the studied indicators of model pine trees (from moderate $-0.31<\mathrm{r}<-0.50$, to very high; $r>0.91)$, weak $(0.11<\mathrm{r}<0.30)-$ with the completeness of plantings and the share of current volume growth with indicators of phytomass components of tree crowns.

Regression mathematical models calculated for estimating the absolute and relative current increment of trunk wood, trunk bark volume, wood mass, bark of branches and mass of needles in absolutely dry condition, in which the arguments are the age and diameter of trees, which characterized by coefficients of 0.72 to 0.92 . In the model for the percentage of needles of the 1-st year of Scots pine, the relationship with the age of the trees is inverse and moderate, but significant at 5-level, the coefficient of determination of the obtained equation is 0.33 .

The developed normative tables of net primary trunk production of wood and net primary production of aboveground part of Scots pine trees showed that with the same diameter, with increasing age of trees - net primary trunk production increases only to a certain age, and reaching a maximum - decreases. With increasing diameter, at the same age - the net primary production of stem wood increases. The net primary production of the aboveground part of trees, as well as the individual components of the aboveground phytomass, increases with age and diameter. In typical forest vegetation conditions of the Eastern Polissya of Ukraine, a medieval tree (50 years old) of Scots pine in the aboveground part can accumulate $15.22 \mathrm{~kg} \cdot$ year $^{-1}$ of net primary production.

The net primary production of Scots pine trunk, obtained according to research, is quite close to similar values determined by the current volume growth of pine trunks in the forests of Ukraine and Moldova.

Key words: temporary test plots; model trees; calculation algorithm; current increment; phytomass components; mathematical models; net primary products. 


\section{Моделирование первичной продукции компонентов надземной части деревьев сосны обыкновенной Восточного Полесья Украины}

\section{Л.Н. Матушевич', П.И. Лакида²}

Первичную продукцию компонентов надземной фитомассы (ствола и кроны деревьев) оценено для деревьев сосны обыкновенной, которые растут преимущественно в чистых и смешанных (примесь от 1 до 3 ед.) сосновых насаждениях искусственного происхождения Восточного Полесья Украины. Насаждения характеризуются как высокопроизводительные (II, I, I и и выше классы бонитета), средне- и высокополнотные, растут в свежих борах $\left(A_{2}\right)$, суборях $(B)$ и сугрудах $\left(C_{2}\right)$. Использовано 80 временных пробных площадей (ВПП), которые заложены в сосновых древостоях Сумской (36 шт.) и Черниговской (44 шт.) областей, на которых срублено и измерено 900 модельных деревьев (МД) сосны, из которых 226 МД с пофракционной оценкой компонентов надземной фитомассы и $674 \mathrm{MД}-$ без оценки фитомассы кроны. Измерение моделей и расчеты первичной продукции компонентов надземной фитомассы деревьев выполнено с помощью усовершенствованных существующих методов и разработанному алгоритму.

Совокупность значений исходных данных в естественных величинах характеризуется нормальным распределением значений по возрасту, диамет-

Матушевич Любовь Николаевна - член-корреспондент Лесной академии наук Украины, кандидат сельскохозяйственных наук, доцент кафедры таксации леса и лесного менеджмента. Национальный университет биоресурсов и природопользования Украины, ул. Героев Обороны, 15, г. Киев, 03041, Украина. Тел.: 044-527-85-23;+38-067-944-82-75. E-mail: Matushevych@ nubip.edu.ua ORCID: https://orcid.org/0000-0001-7282-3215

2 Лакида Петр Иванович - академик Лесной академии наук Украины, первый вице-президент ЛАН Украины, профессор, доктор сельскохозяйственных наук, директор учебнонаучного института лесного и садово-паркового хозяйства. Национальный университет биоресурсов и природопользования Украины, ул. Героев Обороны, 15, г. Киев, 03041, Украина. Тел.: 044-527-85-28; +38-067-462-80-43. E-mail: lakyda@nubip. edu.ua ORCID: https://orcid.org/0000-0003-3639-2969 ру, высоте деревьев и относительной полноте насаждений. Теснота связи существует между всеми исследуемыми показателями модельных деревьев сосны (от умеренной - $0,31<\mathrm{r}<-0,50$, до очень высокой $\mathrm{r}>0,91)$; слабая связь $(0,11<\mathrm{r}<0,30)$ установлена между полнотой насаждений и долей текущего объемного прироста с показателями компонентов фитомассы кроны деревьев.

Рассчитаны регрессионные математические модели для оценки абсолютного и относительного текущего объемного прироста древесины стволов, объема коры стволов, массы древесины, коры ветвей и массы хвои в абсолютно сухом состоянии, в которых аргументами являются возраст и диаметр деревьев $\left(\mathrm{R}^{2}=0,72-0,92\right)$. В модели для оценки процента хвои первого года сосны связь с возрастом деревьев обратная и умеренная, но значимая на 5\%-м уровне при $\mathrm{R}^{2}=0,33$.

Разработанные нормативные таблицы первичной продукции стволовой древесины и первичной продукции надземной части деревьев сосны обыкновенной показали, что при одинаковом диаметре с увеличением возраста деревьев первичная продукция стволовой древесины увеличивается лишь до определенного возраста, а достигнув максимума - уменьшается. С увеличением диаметра при одинаковом возрасте первичная продукция стволовой древесины возрастает. Первичная продукция надземной части деревьев, подобно тому, как и отдельных компонентов надземной фитомассы, с увеличением возраста и диаметра также увеличивается. В типичных лесорастительных условиях Восточного Полесья Украины средневековое дерево (50 лет) сосны обыкновенной в надземной части может накапливать 15,22 кг $\cdot$ год $^{-1}$ первичной продукции.

Первичная продукция стволовой древесины сосны обыкновенной, полученной по данным исследований, достаточно близка к аналогичным значениям, определенных через текущий объемный прирост стволов в культурах сосны обыкновенной Украины и Молдавии.

Ключевые слова: временная пробная площадь; модельные деревья; алгоритм расчета; текущий прирост; компоненты фитомассы; математические модели; первичная продукция. 